Maciej Grochowski

Uniwersytet Mikołaja Kopernika, Toruń

magro@umk.pl

\title{
POSZCZEGÓLNE WŚRÓD OPERATORÓW KWANTYFIKACJI
}

Słowa klucze: współczesny język polski, semantyka, składnia, jednostka leksykalna, kwantyfikacja, kolejność, zbiór

Keywords: contemporary Polish language, semantics, syntax, lexical unit, quantification, sequence, set

\section{Wprowadzenie}

W bogatej literaturze poświęconej wykładnikom kwantyfikacji w języku polskim, a także w krzyżujących się zakresowo z tą literaturą publikacjach dotyczących zaimków (zob. obszerne bibliografie np. w: Karolak 1990; Koseska-Toszewa, Korytkowska, Roszko 2007; Grzegorczykowa 2010; Wierzbicka-Piotrowska 2011; Odrowąż-Sypniewska 2016; Rosalska 2016) brak jest analizy wyrazu poszczególny. Tymczasem obserwacja jego sposobu użycia pozwala przypuszczać, że ma on liczne indywidualne, wymagające zbadania cechy nie tylko semantyczne, lecz również składniowe. Związki między poszczególny a kwantyfikacją potwierdzają definicje słownikowe: we wszystkich słownikach ogólnych współczesnej polszczyzny w definicjach tego wyrazu występuje komponent 'każdy', z kolei w definicjach każdy w SJPD, SJPSz, USJP i SWJP jest użyta forma wyrazu poszczególny (zob. też SEBor: 225, 595). Śladami dystrybutywności tego wyrazu są występujące $\mathrm{w}$ jego definicjach liczne przymiotniki i przysłówki określające podział lub rezultat podziału zbioru; por. np. rozpatrywany (analizowany) pojedynczo, osobno, oddzielnie; pojedynczy, oddzielny (Rosalska 2016). Celem tego artykułu jest analiza składniowo-semantyczna tytułowej jednostki. 
Słowniki współczesnej polszczyzny kwalifikują poszczególny jako przymiotnik. Tylko ISJP uściśla tę charakterystykę, zaliczając go do przymiotników atrybutywnych. Można by ją ująć explicite tak, że poszczególny nie nadaje się na orzecznik, jest składnikiem wyłącznie grupy nominalnej, występującym w antepozycji względem określanego rzeczownika (cechy te łączą badaną jednostkę z operatorem kwantyfikacji ogólnej wszelki, por. Grochowski 200o). W postpozycji przymiotnik nie jest używany: słowniki nie podają ani jednego przykładu użycia postpozycyjnego, a przykład (5), korpusowy, należy zapewne do wyjątków. Por.:

(1) Omawialiśmy poszczególne rozdziały pracy (USJP).

(2) ${ }^{\star}$ Rozdziały pracy, które omawialiśmy, były poszczególne.

(3) Tematy egzaminów ustalały poszczególne kuratoria (ISJP).

(4) ${ }^{\star K u r a t o r i a, ~ k t o ́ r e ~ u s t a l a ł y ~ t e m a t y ~ e g z a m i n o ́ w, ~ b y ł y ~ p o s z c z e g o ́ l n e . ~}$

(5) Są na to dokumenty, wprawdzie część została skonfiskowana, ale to, co było uporządkowane w poszczególnych teczkach poszczególnych zakładów, jak już "Solidarność" normalnie istniała, to po parę tysięcy tych postulatów z przedsiębiorstw poszczególnych było, bo one dotyczyły i spraw oddziałów, i w ogóle produkcji, i wszystkiego (NKJP).

\section{Wielość elementów, podział i otwartość zbioru}

Najistotniejszym atrybutem przypisywanym przez poszczególny przedmiotom i stanom rzeczy nazywanym przez rzeczownik jest 'wielość. Wykładnikiem tego pojęcia są co prawda morfemy liczby mnogiej rzeczownika, ale nie precyzują one takiej 'wielości', która jest implikowana przez badany przymiotnik. Po pierwsze bowiem, wyznacza on granice między przedmiotami tego samego rodzaju bądź stanami rzeczy tego samego rodzaju, nazywanymi przez rzeczownik, dzieląc hipotetyczny zbiór takich przedmiotów bądź stanów rzeczy na jednorodne elementy; por. np.:

(6) Stan zdrowia poszczególnych kuracjuszy był różny.

(7) Nad przebiegiem rozmów czuwały komisje strajkowe w poszczególnych zakładach (NKJP).

(8) Należy starać się rygorystycznie kontrolować poszczególne etapy rozumowania (NKJP).

(9) Morfologia poszczególnych stadiów larwalnych jest taka sama jak u dzisiejszych prymitywnych skorupiaków (NKJP).

W związku z tym nie łączy się z collectivami należącymi do singulariów tantum (typu klientela, konnica, igliwie, umeblowanie), nie implikują one bowiem żadnych granic zbiorowości (Bogusławski 1973: 20). Dyskusyjna jest łączliwość poszczególne 
z rzeczownikami nazywającymi zbiór, którego podział na stany rzeczy tego samego rodzaju nie jest oczywisty, jak np. w wypadku okoliczności; por.:

(10) ?Żołnierz musi sobie radzić w poszczególnych okolicznościach.

z bezdyskusyjnie akceptowalnym użyciem innych operatorów kwantyfikacji w połączeniu z tym samym rzeczownikiem:

(11) Żołnierz musi sobie radzić w każdych / we wszystkich / we wszelkich okolicznościach.

Badany wyraz nie łączy się z rzeczownikami odnoszącymi się do przedmiotów amorficznych (substancjalnych), przypisany bowiem takiemu przedmiotowi predykat implikuje przypisanie go dowolnej części tego przedmiotu (Bogusławski 1973: 7). W takich wypadkach granice między przedmiotami można wyznaczać jedynie w sposób zewnętrzny, za pomocą predykatów morficznych, albo metajęzykowo; por. dewiacyjne:

(12) ${ }^{*}$ Z zamarzniętego jeziora wystawały poszczególne żelaza.

(13) $\quad{ }^{\star} \mathrm{Na}$ deser serwowano poszczególne lody/koniaki.

$\mathrm{z}$ akceptowalnymi:

(14) Z zamarzniętego jeziora wystawały poszczególne kawałki żelaza.

(15) Na deser serwowano poszczególne rodzaje lodów / gatunki koniaków.

Po drugie, przymiotnik poszczególny charakteryzuje wspomnianą 'wielość' jako liczbowo nieokreśloną, a zbiór nazywany przez rzeczownik jako otwarty. Oba sądy wymagają szerszego komentarza. Badany wyraz zajmuje pozycję składniową analogiczną do operatorów kwantyfikujących wszystkie, niektóre, a także liczebników głównych (o analogii pozycji jednostek tych dwóch ostatnich klas w: Bogusławski 1966: 49-51). Kookurencja poszczególny z liczebnikami w tej samej grupie nominalnej jest niedopuszczalna, por. np.:

(16) Poszczególni zawodnicy wykonywali skoki.

(17) ^Poszczególnych sześciu zawodników wykonywało skoki.

Niemożliwe jest również skwantyfikowanie grupy imiennej z atrybutem poszczególny za pomocą liczebnika użytego w orzeczniku; np.:

(18) *Poszczególnych zawodników było sześciu. 
Analogiczne właściwości mają operatory niektóre i wszelkie, przeciwne operator wszystkie; por.:

(19) *Niektórych sześciu zawodników wykonywało skoki.

(20) *Wszelkim dwudziestu uczestnikom wycieczki skradziono paszporty.

(21) *Niektórych zawodników było sześciu.

(22) *Wszelkich uczestników wycieczki było dwudziestu.

(23) Zaprosił wszystkich dziesięciu studentów na swoje seminarium.

(24) Wszystkich studentów było dziesięciu.

Obiektem charakterystyki za pomocą atrybutu poszczególny może być nie tylko jednostkowy element zbioru, jak w wypowiedzeniach (6), (8), (9), (16), a więc na przykład zbioru kuracjuszy czy zawodników, zbioru etapów rozumowania czy stadiów larwalnych, ale również wieloelementowy zbiór interpretowany globalnie jako jeden element zbioru nadrzędnego. Takie wieloelementowe zbiory, liczbowo jednorodne, mogą być scharakteryzowane za pomocą rzeczownikowego wykładnika kwantyfikacji, w tym rzeczownika odliczebnikowego (Zaron 200o: 315; por. też Bednarek 1994), a następnie omawianego przymiotnika, np.:

(25) Tuż przed turniejem długo tasowali poszczególne talie kart do brydża.

(26) Już od maja na kilku naszych halach pasterze pilnują poszczególnych stad owiec wełnistych.

(27) Poszczególne grupy zawodników wykonywały skoki.

(28) Poszczególne szóstki zawodników wykonywały skoki.

(29) Poszczególne trójki studentów zdawały egzamin.

Skoro zbiór denotowany przez rzeczownik, którego atrybutem jest poszczególny, odznacza się otwartością, odpowiednia fraza nominalna ma referencję nieokreśloną. Jest więc zrozumiałe, że badany wyraz nie łączy się z formami zaimków wskazujących ani osobowych (analogicznie do każdy i wszelki) i nie tworzy konstrukcji elektywnych (analogicznie do wszelki). Por. np. ${ }^{*}$ te poszczególne / ${ }^{\star}$ ci poszczególni; *one poszczególne / * my poszczególni; ${ }^{*}$ poszczególni z nich.

\section{Sekwencyjność}

Ze znaczenia wyrazu poszczególny wynika, że określany zbiór przedmiotów bądź stanów rzeczy musi być co najmniej trójelementowy, nie wynika natomiast, że wszystkim elementom zbioru nazywanego przez rzeczownik przysługuje dana cecha. Poszczególny jest atrybutem neutralnym względem opozycji niektóre - wszystkie. Nie są dewiacyjne wypowiedzenia: 
(30) Remontują poszczególne mieszkania, ale nie wszystkie.

(31) Remontują poszczególne mieszkania, ale tylko niektóre.

(32) Porównywano poziom inflacji w poszczególnych latach, ale nie we wszystkich.

(33) Porównywano poziom inflacji w poszczególnych latach, ale tylko w niektórych.

Wewnętrznie sprzeczne są natomiast wypowiedzenia:

(34) ${ }^{\star}$ Odbiór świadectw podpisali poszczególni uczniowie, ale zrobił to tylko jeden uczeń.

(35) ^Przybywające na uroczystość rodziny medalistów zajmowały poszczególne stoliki, to znaczy dwa.

(36) ${ }^{\star}$ Goście przyjmowali z radością poszczególne toasty powitalne, mianowicie dwa.

(37) ${ }^{\star}$ Wiersze jubilata czytali poszczególni aktorzy Teatru Dramatycznego, ale robiło to tylko dwóch aktorów.

Hipoteza o trójelementowości jako minimalnej liczebności zbioru charakteryzowanego przez poszczególny wymaga komentarza. Znaczenie omawianego wyrazu sugeruje, że stany rzeczy, do których się on odnosi lub o których mowa w wypowiedzeniu, nie zachodzą równocześnie, tylko następują w określonej kolejności: każdy z nich, oprócz pierwszego, ma miejsce później niż inny (co najmniej jeden). Co prawda kolejność stanów rzeczy nie jest znana i jej wykładnikiem nie może być wyraz poszczególny (bo jej nie precyzuje), ale zawsze jest założona, pozwala ją ujawnić kontekst uzupełniający treść danego wypowiedzenia. Kolejność, nawet jeżeli nie jest niczym zdeterminowana bądź odznacza się totalnym chaosem, jest zawsze określona; inne pojęcie kolejności jest wewnętrznie sprzeczne; por. np.:

(38) Świadectwa wręczano poszczególnym uczniom w kolejności alfabetycznej / w kolejności od najlepszych.

(39) ^Świadectwa wręczano poszczególnym uczniom, ale nie robiono tego w żadnej kolejności.

Jedna z zasadniczych różnic semantycznych między wykładnikami pojęć następstwa i kolejności polega na tym, że pierwsze odnosi się do relacji dwuargumentowej (do opozycji wcześniej - później czy, krótko mówiąc, przed - po), drugie natomiast do relacji wieloargumentowej, a więc obejmującej co najmniej trzy człony. Tezę tę uzasadniłem w innym miejscu (Grochowski 2004), w wyniku analizy między innymi opozycji następny - kolejny i następnie - z kolei.

Liczne przykłady wypowiedzeń z wyrazem poszczególny potwierdzają w sposób jawny istnienie wieloelementowego szeregu stanów rzeczy lub przedmiotów, np.: 
(40) Realizujemy poszczególne zamówienia towarów na wesela, chrzciny i komunie według kolejności zgłoszeń.

(41) Opowiem wam, o czym jest mowa w poszczególnych odcinkach serialu.

Pojęcie kolejności jest niewątpliwym komponentem znaczenia poszczególny i zawsze może być wykryte w wyniku jego analizy. Przedmioty tworzące szereg są rozważane przez mówiącego w określonej kolejności, to znaczy, że o każdym z nich myśli on niezależnie od innych przedmiotów, wcześniej lub później niż o pozostałych. Por. np.:

(42) Poszczególne klatki niektórych bloków posiadały numerację sąsiedniej ulicy (NKJP).

(43) Potwierdzona została teza, że poszczególne przejawy dewiacji występują z reguły łącznie (NKJP).

Nadawca wypowiedzenia (42) nie wie, ile klatek ma numerację sąsiedniej ulicy, ale żeby dojść do konstatacji, że jest ich wiele, rozpatruje pod tym względem każdą klatkę niezależnie od pozostałych, a więc wcześniej lub później niż inne klatki. Można przyjąć również, że autor tezy zawartej w wypowiedzeniu (43) rozpatrywał każdy przejaw dewiacji z punktu widzenia możliwości współwystępowania z innymi i że każdym przejawem zajmował się wcześniej lub później niż pozostałymi. Z tej wstępnej analizy wypowiedzeń (42), (43) wynika, że stany rzeczy charakteryzowane przez poszczególny są rozważane osobno. Potwierdzeniem tej hipotezy jest pleonastyczność wypowiedzeń, w których badany przymiotnik współwystępuje z przysłówkiem dystrybutywnym (Rosalska 2016) lub innym wykładnikiem dystrybutywności (np. przyimkiem po; Bogusławski 2011); por. np.:

(44) *Poszczególne zeszyty czasopisma publikowano osobno.

(45) *Poszczególne kanapki pakowałem osobno w folię aluminiową.

(46) *Poszczególne dziewczynki dostały po dwie lalki.

Akceptowalność kontekstów wyrazu poszczególny, w świetle których można przypuszczać, że stany rzeczy określane przez ten wyraz nie tworzą co najmniej trójelementowej sekwencji, jest w wielu wypadkach dyskusyjna. Omawiany przymiotnik dominuje w zdaniach konstytuowanych przez czasownik niedokonany, np.:

(47) Poszczególni studenci Wydziału Prawa zdawali egzamin z prawa karnego.

(48) Na stację wjeżdżały poszczególne pociągi dalekobieżne.

(49) Do okienka kasowego podchodzili poszczególni interesanci.

(50) Z sufitu na podłogę spadały poszczególne krople brudnej wody. 
Analogiczne zdania tworzone przez czasownik dokonany, w świetle NKJP zdecydowanie rzadsze, budzą wątpliwości, por.:

(51) ?Poszczególni studenci Wydziału Prawa zdali egzamin z prawa karnego.

(52) ?Na stację wjechały poszczególne pociągi dalekobieżne.

(53) ?Do okienka kasowego podeszli poszczególni interesanci.

(54) ?Z sufitu na podłogę spadły poszczególne krople brudnej wody.

Konteksty, w których przymiotnik poszczególny odnosi się do nazwy wykonawcy czynności, są rzadsze niż te odnoszone do nazwy obiektu czynności (patiensa) bądź nosiciela cechy. Typowymi kontekstami badanego wyrazu są na przykład wypowiedzenia:

(55) Na pewno tu kiedyś była, rozpoznawała poszczególne domy, nieoglądane od lat (NKJP).

(56) Książka Ziembickiej opowiada tyle o poszczególnych malarzach i rytownikach, co o Akademii właśnie (NKJP).

(57) Przyklejona policzkiem do drzwi, podsłuchiwałam, łowiąc poszczególne słowa $\mathrm{z}$ dziwnych, niezrozumiałych rozmów rodziców na temat wysokich blondynów w skórzanych płaszczach (NKJP).

W wypowiedzeniach, w których nie jest komunikowana żadna czynność ani w których nie mówi się nic o żadnym dzianiu się czegoś, użycie przymiotnika poszczególny często trudno jest zaakceptować (aczkolwiek warunkiem adekwatności wypowiedzeń z tym wyrazem nie jest komunikowanie o tego rodzaju stanach rzeczy; por. (64), (65)). Typowymi przykładami takich ciągów nieakceptowalnych (przypuszczalnie z powodu ich oczywistości) są wypowiedzenia:

(58) *Poszczególne ołówki leżą na biurku.

(59) *Poszczególni uczniowie siedzą w ławkach.

(analogiczne zdania z każdy i żaden kwestionowała przed laty Jolanta Rokoszowa (1986) w swoim studium o kwantyfikacji, odwołując się do reguł wnioskowania z kwadratu logicznego).

Por. z niebudzącymi wątpliwości:

(60) Wszystkie/niektóre ołówki leżą na biurku.

(61) Wszyscy/niektórzy uczniowie siedzą w ławkach.

(62) Z kieszeni wypadały mi poszczególne ołówki.

(63) Po skończonej lekcji z klasy wybiegali poszczególni uczniowie. 
Ołówki leżące na biurku nie tworzą wewnętrznie uporządkowanego zbioru z punktu widzenia kolejności, w jakiej można by myśleć o jego elementach. Ich charakterystyka za pomocą przymiotnika poszczególny jest więc nieadekwatna w stosunku do faktycznego stanu rzeczy. Jedną z relewantnych cech semantycznych implikowanych przez ten przymiotnik jest to, że o każdym elemencie zbioru nazywanego przez określany rzeczownik (bez względu na liczbę tych elementów) myśli się osobno, niezależnie od pozostałych elementów tego zbioru. A zatem podstawą relacji semantycznej komunikowanej przez poszczególny jest pojęcie kolejności, nie jest natomiast pojęcie dziania się (to ostatnie zaś jest komponentem znaczeniowym przysłówka osobno; Rosalska 2016). Por. przykłady potwierdzające tę tezę:

(64) W razie zbycia spadku spadkobierca nie ponosi odpowiedzialności z tytułu rękojmi za wady fizyczne i prawne poszczególnych przedmiotów należących do spadku (NKJP).

(65) Zachowanie się, ogólna sylwetka, kształt i budowa poszczególnych części ciała oraz barwa sukni pozwalają na przybliżoną ocenę wieku kozła (NKJP).

\section{Pluralis - podstawowa wartość gramatyczna jednostki}

Skoro wyróżnione zostały komponenty semantyczne przymiotnika poszczególne, można przyjąć, że następnym krokiem postępowania badawczego powinno być uściślenie zależności między nimi i zaproponowanie reprezentacji semantycznej wyrazu. Wcześniej jednak należałoby ustosunkować się do jego charakterystyk zastanych, to znaczy do definicji słownikowych. Definicje wyrazu poszczególny w słownikach współczesnej polszczyzny mają status definicji przedmiotowych, ale nie spełniają warunków definicji równościowej (Grochowski 1993), stanowią jedynie wyliczenie bliskoznaczników wyrazu hasłowego wraz z ich atrybutami. Przyznać jednak trzeba, że większość bliskoznaczników została trafnie dobrana; zasadnicze wątpliwości dotyczą tylko przymiotników niektóry i szczegółowy (SJPD, SJPSz, USJP, SWJP).

Definicja poszczególny w ISJP różni się strukturalnie i semantycznie od definicji podanych w pozostałych słownikach: „Poszczególne rzeczy, osoby, zjawiska itp. to takie, które bierzemy pod uwagę pojedynczo, każde z osobna”. Ma formę zdania złożonego względnego, jest definicją kontekstową i zarazem dwustopniową. Druga jej część może być interpretowana jako komentarz do części pierwszej, służy mianowicie wyjaśnieniu tego, co to znaczy, że „rzeczy, osoby, zjawiska [...] bierzemy pod uwagę pojedynczo". Ale najistotniejsza różnica między definicją w ISJP a definicjami w pozostałych słownikach polega na tym, że tylko w ISJP definiendum ma formę liczby mnogiej (mianownika rodzaju niemęskoosobowego). Wybór tej formy jest trafny, choć jest ona niezgodna $\mathrm{z}$ formą wyrazu hasłowego. Ta ostatnia powinna mieć również postać pluralis. 
Po pierwsze, w żadnym słowniku ogólnym współczesnej polszczyzny nie ma ani jednego przykładu użycia badanego wyrazu w formie liczby pojedynczej. W świetle przedstawionej dotychczas analizy oraz podanych niżej faktów nie jest to przypadek. Niezgodność formy wyrazu hasłowego z materiałem dokumentacyjnym została jednak we wszystkich słownikach przemilczana. Po drugie, na 144 wystąpienia jednostki poszczególny, zarejestrowane w SFPW, tylko 3 mają postać singularis. Po trzecie, $\mathrm{w}$ zbiorze blisko 31000 wypowiedzeń z formami wyrazu poszczególny, zarejestrowanych w podkorpusie zrównoważonym NKJP, wypowiedzenia, w których wyraz ten jest użyty w formie singularis, stanowią około 1\% (niektóre rzeczowniki konstytuujące badaną frazę często się powtarzają; np. człowiek, osoba, obywatel, pracownik, rzecz). Są to więc użycia bardzo rzadkie. Po czwarte, w ogromnej większości wypowiedzeń formę liczby pojedynczej poszczególny można - po dokonaniu również innych koniecznych operacji gramatycznych - zastąpić formą liczby mnogiej (do wyjątków należą połączenia przymiotnika z singulariami tantum, np. poszczególne życie). Próby przekształceń w kierunku przeciwnym są z reguły bezskuteczne i prowadzą do dewiacji. Por. np.:

(66) Stopień użytkowania dobra publicznego przez poszczególnego obywatela / poszczególnych obywateli może być i jest różny (NKJP).

(67) Gdy analizuję rejsy innych, mniej interesuje mnie, jaka była trasa poszczególnej/poszczególnych podróży, więcej natomiast, w jakim stylu została odbyta (NKJP).

(68) Poszczególne okresy życia i twórczości Niemena są udokumentowane w sposób mocno zróżnicowany (NKJP). $\rightarrow$ *Poszczególny okres życia i twórczości Niemena jest udokumentowany w sposób mocno zróżnicowany.

(69) Przy pracach polegających na dozorze urządzeń może być wprowadzony, w poszczególnych dniach i tygodniach / ${ }^{*} \mathrm{w}$ poszczególnym dniu i tygodniu, dłuższy czas pracy (NKJP).

Po piąte, abstrahując od ograniczeń pragmatycznych zakresu użycia poszczególny (o tym szerzej na końcu artykułu), warto zwrócić uwagę, że w formie liczby pojedynczej przymiotnik ten występuje w specyficznych kontekstach. Są to konstatacje, a przede wszystkim zdania ogólne, typowe dla aktów prawnych i wypowiedzi logiczno-filozoficznych. Rzeczownik, którego atrybutem jest poszczególny, reprezentuje w takich użyciach nazwę gatunkową (rodzajową), por. np.:

(70) Kto publicznie lży, wyszydza lub poniża grupę ludności lub poszczególną osobę z powodu jej bezwyznaniowości lub przynależności wyznaniowej, podlega karze pozbawienia wolności do lat trzech (Kodeks karny).

(71) Liczba godzin nadliczbowych przepracowanych w związku z okolicznościami określonymi w $\$ 1$ pkt 2 nie może przekroczyć dla poszczególnego pracownika 4 godzin na dobę (Kodeks pracy). 
(72) Skoro możemy mentalnie unicestwić każdą rzecz poszczególną, wyobrażamy sobie, że możemy unicestwić całość i myśleć o pustej przepaści, która zajmie miejsce wszechświata (Leszek Kołakowski, Bergson, 1985).

Akceptowalne jest wypowiedzenie, w którym rzeczownik w singularis jest użyty generycznie, dewiacyjne zaś takie, w którym nada mu się referencję określoną, por. np.:

(73) Mundur musi mieć poszczególny żołnierz.

(74) ${ }^{\star}$ Na przepustkę wyszedł poszczególny żołnierz.

Szukając odpowiedzi na pytanie, dlaczego obiektem definicji słownikowych jest forma singularis mimo śladowej ilości przykładów użycia przymiotnika w tej formie, stawiam hipotezę, że autorzy definicji zgodnie (lub jeden za drugim) uznali, że najistotniejszym komponentem znaczenia badanego przymiotnika jest 'każdy'. Zapewne trudno byłoby wyeliminować ten sens z charakterystyki semantycznej poszczególny, o czym świadczą choćby wyraźnie pleonastyczne wypowiedzenia (jest ich w NKJP kilkadziesiąt), w których przymiotnik ten współwystępuje z formą wyrazu $k a \dot{z} d y$, por. np.:

(75) ${ }^{\star}$ To globalne rozszczepienie naszego społeczeństwa odwzorowuje się w każdym poszczególnym przejawie jego codziennego bytu (NKJP).

(76) *Tłum musi się rozejść, każdy poszczególny człowiek przypatrzyć się dobrze sobie samemu i potem innym objawić (NKJP).

Niemniej jednak za najwyżej stojący w hierarchii składników treści poszczególny trzeba, jak to wcześniej pokazałem (w punkcie 2.), uznać 'wielość. Temu pojęciu jest podporządkowany sposób myślenia o stanowiących sekwencję elementach zbioru, polegający na tym, że o każdym z nich myśli się niezależnie od pozostałych. Poza tym uznanie sensu 'każdy' za nadrzędny komponent semantyczny przymiotnika poszczególny nie jest trafne, ponieważ z jego znaczenia nie wynika, że nie istnieją takie obiekty i stany rzeczy, których dany predykat (określany przez poszczególny) nie dotyczy; por. akceptowalne (30), (32). Nie jest też wykluczone, że wybór nominatiwu singularis na formę hasłową i zarazem definiendum nie ma głębszej motywacji merytorycznej i że stanowi jedynie pochodną przyzwyczajenia leksykografów do rozpowszechnionych zasad hasłowania i definiowania.

Spośród składników definiensa, występujących we wszystkich znanych mi definicjach wyrazu poszczególny, najbliższe semantycznie definiendum są wyrażenia każdy/każde z osobna (SJPD, SJPSz, ISJP, USJP) i każdy $z$ wielu (SWJP, WSJP). Współwystępując z komentarzem 'analizowany/rozpatrywany pojedynczo/osobno', całkiem nieźle odzwierciedlają sens przymiotnika poszczególny, choć nie przedsta- 
wiają jego struktury. Poza tym, jak to przekonująco uzasadniła Paulina Rosalska (2016: 192), każdy z osobna odnosi się zawsze do argumentów predykatów czynnościowych, na przymiotnik poszczególny natomiast, jak to wynika z przedstawionej tu analizy, nie są nałożone takie ograniczenia.

Ciąg każdy z osobna jest jednostką języka z tzw. członem izolowanym ( $z$ osobna) i jako taki nie jest trafnie wybranym składnikiem definicji. W NKJP, w podkorpusie zrównoważonym, na 960 przykładów użycia ciągu $z$ osobna w blisko 900 wypowiedzeniach współwystępuje on z formą wyrazu każdy, w kilkunastu wypowiedzeniach $\mathrm{z}$ formą wyrazu żaden, a w sześciu $\mathrm{z}$ formą wyrazu poszczególny ( $\mathrm{w}$ tym w dwóch z każdy i poszczególny łącznie, ewidentnie pleonastycznych). Por.:

(77) ${ }^{\star} \mathrm{Na}$ to pytanie starano się odpowiedzieć na spotkaniu kierownictwa ŁKS z poszczególnymi piłkarzami z osobna i kadrą szkolącą (NKJP).

(78) `Zbiorowość egoistów doskonałych nie może istnieć bez nieustannego udaremniania zakusów każdego poszczególnego egoisty z osobna (NKJP).

Formy wyrazów, z którymi kookuruje $z$ osobna, tworzą klasę substytucyjną zamkniętą, a wraz z tym ciągiem stanowią leksykalne jednostki języka. O ich cechach gramatycznych zob. Grochowski 2006.

\section{Konkluzja}

Podsumowując analizę semantyczną przymiotnika poszczególny, proponuję taką oto reprezentację jego struktury treści:

- poszczególne X-y:

'mówiący wie, że X-ów jest wiele i że są to rzeczy tego samego rodzaju;

nie wie, ile jest X-ów;

myśli o X-ach w taki sposób, że o każdym z nich myśli wcześniej lub później niż o pozostałych'.

Jeżeli przyjmie się szerokie rozumienie kwantyfikacji jako charakterystyki ilościowej argumentu predykatu (a więc szersze niż to, które przyjmuje się w logicznym rachunku kwantyfikatorów), to można wyrazić pogląd, że jednostka poszczególne jest jednym $z$ operatorów kwantyfikacji dystrybutywnej. Od podstawowego jej wykładnika każdy różni się, jak to próbowałem uzasadnić w tym artykule, sekwencyjnością oraz brakiem obligatoryjnej kompletności zbioru (nie wszystkim elementom zbioru określanego przez poszczególne musi przysługiwać dany predykat). 


\section{Uwagi uzupełniające}

Na zakończenie jeszcze dwa krótkie komentarze do artykułów słownikowych poświęconych wyrazowi poszczególny.

Uwaga pierwsza. Przyjmując klasyfikację leksemów odmiennych według kryteriów fleksyjnych (dziś już mało oryginalną i nietwórczą), uznaje się poszczególny za przymiotnik. Ale podporządkowanie jego odmiany kategorii stopnia, a ściślej wartości stopnia równego (por. WSJP), jest zaskakujące. Po pierwsze, nie ma podstaw do przyjmowania założenia, że przymiotniki odmieniają się przez stopień; nawet jeżeli rozumieć odmianę jako operację mechaniczną (bez jej związku ze znaczeniem pojęcia stopień), to podlega jej tylko część jednostek tej klasy. Po drugie, każdy odbiorca słownika widząc napis „stopień równy”, oczekuje w sposób zupełnie naturalny wartości również innych form stopnia.

Uwaga druga. Przymiotnik poszczególny ma ograniczony zakres użycia. Z faktu tego zdał sprawę w sposób lakoniczny, za pomocą kwalifikatora książk., tylko USJP. Taki opis ograniczeń pragmatycznych jest wysoce niewystarczający. Już SFPW pokazał, że wyraz poszczególny (144 wystąpienia ogółem) jest używany w zasadzie tylko w trzech stylach: w tekstach popularnonaukowych (45/144), w tekstach drobnych wiadomości prasowych (34/144) i w publicystyce (58/144). Przykłady wystąpień w prozie artystycznej (6/144) i w dramacie artystycznym (1/144) są śladowe. Materiał zawarty w NKJP potwierdza intuicyjnie tę opinię, ale pożądane byłyby nowe badania statystyczne. Przegląd źródeł cytatów skłania do refleksji, że wyraz poszczególny dominuje w tekstach publicystycznych i urzędowych (dotyczących prawa, zarządzania, ekonomii i finansów) i że prawie nie występuje w tekstach języka potocznego i literatury pięknej.

\section{Literatura}

BednAReK A., 1994, Leksykalne wykładniki parametryzacji świata. Studium semantyczne, Toruń.

BogusŁaWsKi A., 1966, Semantyczne pojęcie liczebnika i jego morfologia w języku rosyjskim, Wrocław.

BogusŁAwski A., 1973, Nazwy pospolite przedmiotów konkretnych i niektóre właściwości ich form liczbowych i połączeń z liczebnikami w języku polskim, [w:] Z. Topolińska, M. Grochowski (red.), Liczba, ilość, miara, Wrocław, s. 7-35.

BogusŁawski A., 2011, Polskie po dystrybutywne: jednolitość ilościowego podziału zbiorowości, „Prilozi MANU” 36, s. 81-95.

Grochowski M., 1993, Konwencje semantyczne a definiowanie wyrażeń językowych, Warszawa.

Grochowsкi M., 2000, Funkcja intratekstualna leksemów a ich cechy gramatyczne (Analiza wyrażenia wszelki), „Poradnik Językowy” nr 5, s. 1-8. 
Grochowski M., 2004, Succession and sequence. Semantic relations, „Studies in Polish Linguistics" t. 1, s. 61-80.

Grochowski M., 2006, Status gramatyczny i semantyczny wyrażenia z osobna, „Poradnik Językowy" nr 9, s. 41-47.

Grzegorczy Kowa R., 2010, Wprowadzenie do semantyki językoznawczej, Warszawa.

ISJP: M. Bańko (red.), Inny słownik języka polskiego, Warszawa 2000.

KAROLAK S., 1990, Kwantyfikacja a determinacja w jezzykach naturalnych, Warszawa.

Koseska-Toszewa V., Korytкowska M., Roszko R., 2007, Polsko-bułgarska gramatyka konfrontatywna, Warszawa.

NKJP: Narodowy Korpus Języka Polskiego, www.nkjp.pl.

Odrowąż-Sy PNIEWSKa J., 2016 (red.), Przewodnik po filozofii języka, Kraków.

Rokoszowa J., 1986, Czy żaden to każdy nie?, „Język Polski” LXVI, s. 242-249.

RosAlska P., 2016, Relacje między przysłówkami kolektywnymi a syngulatywnymi i dystrybutywnymi we współczesnym języku polskim, Uniwersytet Mikołaja Kopernika, rozprawa doktorska, mszps.

SEBor: W. Boryś, Słownik etymologiczny języka polskiego, Kraków 2005.

SFPW: I. Kurcz, A. Lewicki, J. Sambor, K. Szafran, J. Woronczak, Słownik frekwencyjny polszczyzny współczesnej, Kraków 1990.

SJPD: W. Doroszewski (red.), Słownik języka polskiego, Warszawa 1958-1969.

SJPSz: M. Szymczak (red.), Słownik jezzyka polskiego, Warszawa 1978-1981.

SWJP: B. Dunaj (red.), Słownik współczesnego języka polskiego, Warszawa 1996.

USJP: S. Dubisz (red.), Uniwersalny słownik języka polskiego, Warszawa 2003.

Wierzbicka-Piotrowska E., 2011, Polskie zaimki nieokreślone. Wybrane zagadnienia semantyczne, syntaktyczne i pragmatyczne, Warszawa.

WSJP: P. Żmigrodzki (red.), Wielki słownik języka polskiego PAN, www.wsjp.pl.

ZARON Z., 2000, Zbiór jako kategoria semantyczna. Jej wykładniki w polszczyźnie, „Annales Universitatis Mariae Curie-Skłodowska” „Sectio FF: Philologiae” t. 18, s. 311-322.

\section{Poszczególne 'individual' among quantification operators Summary}

The paper presents a syntactic and semantic analysis of a Polish lexical unit poszczególne 'individual'. It contains a description of the limits of its use, and a proposition of representation of its meaning. Moreover, it justifies the hypothesis that the meaning of poszczególne implies the notions of multitude, ordering, and openness of the set, and that the unit is one of the operators of distributive quantification. 